\title{
DOI:http://dx.doi.org/10.4314/ljh.v26i1.6
}

\section{Art Studies in Ghana: Whose Responsibility?}

\author{
Kwame Amoah Labi \\ Senior Research Fellow, Institute of African Studies, \\ University of Ghana, Legon
}

\begin{abstract}
While Ghana has centuries of tradition in producing some significant art, the literature on Ghanaian art suggests a preponderance of Euro-American writing about it, and on the contrary a paucity of Ghanaian scholars' contribution to the country's art studies. This paper examines some of the scholarship and Ghanaian participation in art discourse. It proposes some measures to change the trend by introducing art history departments focusing on degree programmes and graduate studies, and creating a local platform for indigenous voices and perspectives to cross-fertilize the knowledge in the discipline for the enrichment of the global discourse on Ghana's art.
\end{abstract}

Keywords: art studies, scholarship, African art, art history, faculty

This paper is about the minimal Ghanaian scholars' participation in art studies despite centuries of local art production. On the contrary, there is abundant literature on the country's art published largely by Euro-Americans from around the seventeenth century to date. For example, Wilhelm Müller (1983), writing about the Fetu (Fante) military accoutrements and basing his accounts on seventeenth century records, says Fetu weapons were decorated and were 'extremely beautiful and clean' (p. 196). William Bosman (1705/1967), also writing in the early eighteenth century, challenged European craftsmen to match the quality of works from the Coast of Guinea (pp. 128-129). Figures 1a-c taken from John Barbot's (1732/1992) drawings of Gold Coast decorated bangles, bracelets, hair slides, stools and jewellery attest to this rich art tradition. Similarly, European interest in other African artistic creations led to their extensive collection and shipment to European homes and museums. 


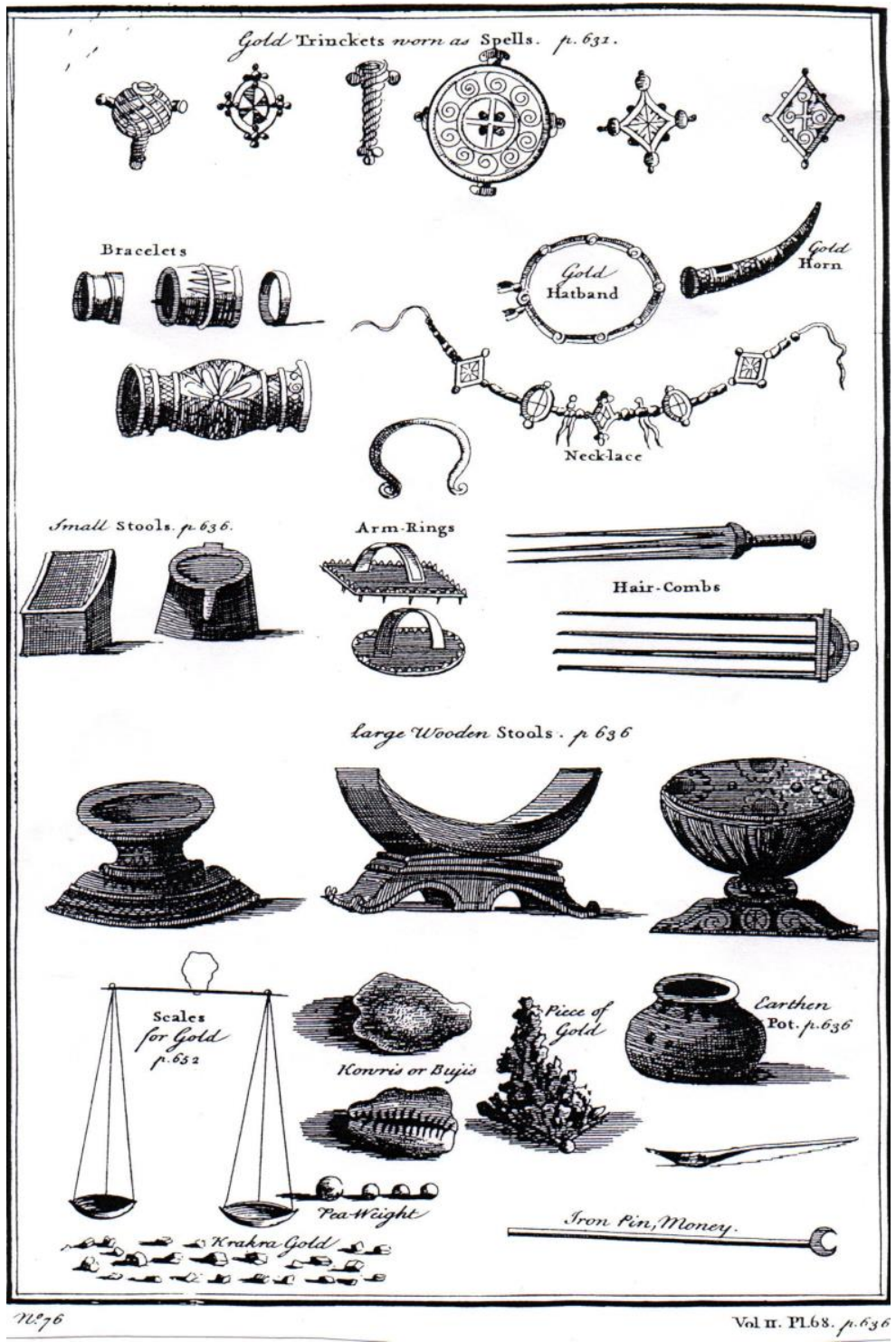

Fig. 1a. An assortment of jewellery, hair slides and other art forms used on the Gold Coast. Photo: John Barbot, 1732, Vol. 2: 693, Pl. 69. 
Labi K. A./ Legon Journal of the Humanities 26 (2015) 99-124
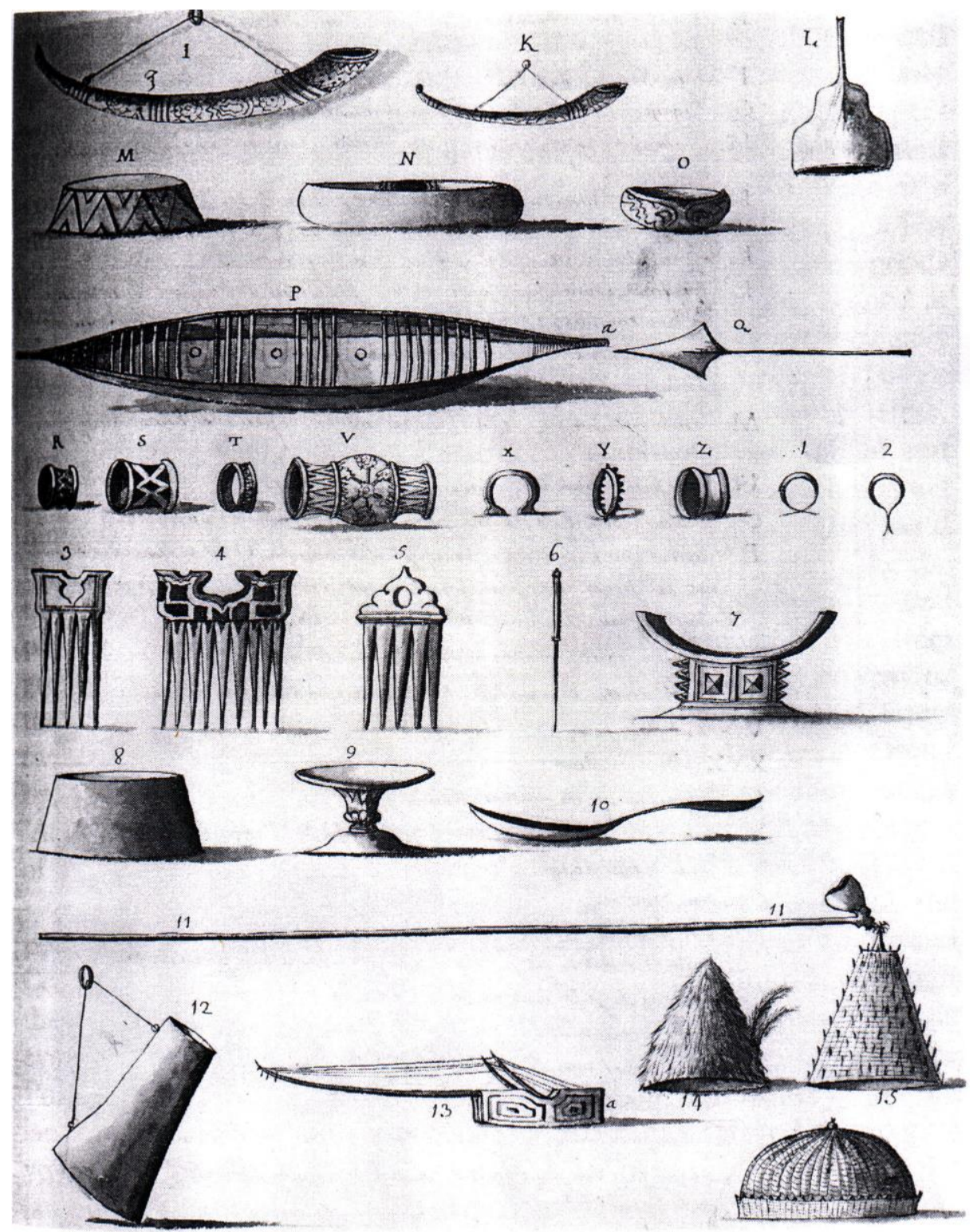

Fig. 1b. Gold Coast artefacts in wood, meal and ivory. Photo: John Barbot, 1992, Vol. 2: p. 570, Fig. 47. 


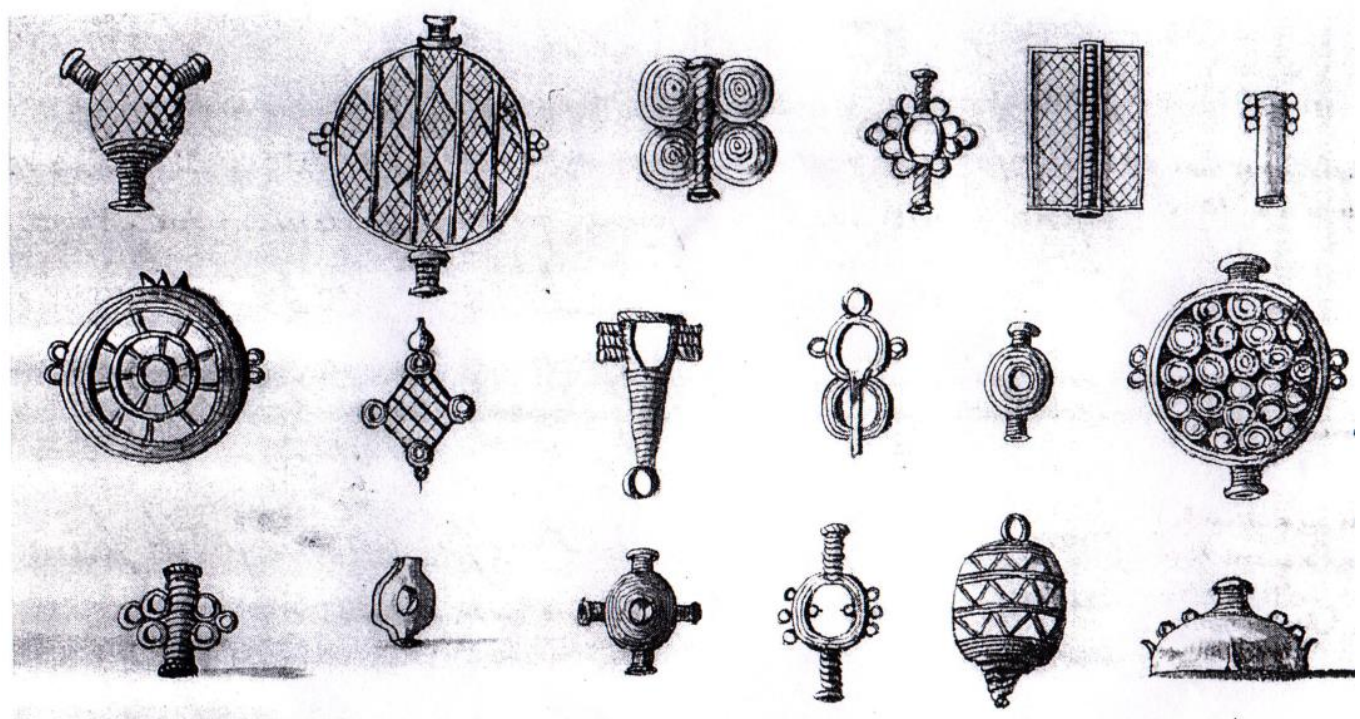

oast

Fig. 1c. Gold trinkets from the Gold Coast. Photo: John Barbot, 1992, Vol. 2: p. 494, Fig 43.

Subsequently, the British Colonial Officer and anthropologist Robert Rattray (1927), notes in the opening decades of the twentieth century that he took advantage of Europeans collecting gold weights at the time by commissioning seventy brass works for the annual British Empire exhibition held between 1924-5 in London (pp. 306-309). Such art collections taken to Europe, and the early European written sources led to scientific inquiry into African art.

African art, as an area of art historical studies, is a recent inception, which emerged as a discipline in European and American universities in the mid-twentieth century, and was introduced into Ghanaian tertiary institutions in 1952 (Labi, 2013, p. 18). Roy Sieber was the first to be awarded a $\mathrm{PhD}$ in 1957 from the State University of Iowa (Blier, 1990, p. 92). Consequently, there has been a missing link between art production and its scholarship in Ghana, raising concerns about how this gap between practice and theory can be bridged. How can Ghanaians create a forum for critical perspectives, which take into consideration indigenous thought, develop methodologies, participate in art discourses and respect local epistemologies without subjecting them to western scrutiny? 
This paper therefore examines art studies in Ghana, and calls for critical local voices and perspectives to diversify knowledge on Ghana's art. It invites the attention of faculty, art practitioners, scholars and the public as well as challenges stakeholders to develop the discipline.

While formal education in Ghana began in the $19^{\text {th }}$ century, art education had to wait till the founding of Achimota School, Accra, in 1927. The formal teaching of art in Achimota School from 1927 onwards yielded interesting results as recounted by Coe (2002), Labi (2013) and Woets (2014). G. Stevens, the first art teacher, introduced art history lessons into the art curricula. He had reproductions of the works of Rafaello Sanzio da Urbino, Peter Paul Rubens, Leonardo da Vinci together with sculptures and plaster casts of other European artists in the Art Department. Below these, he wrote short comments illustrating the merit in each (Achimota Review 1927-1937, 1937, p. 38). Woets (2014) informs us that Stevens also showed slides of works from the Belgian Congo (now Democratic Republic of Congo), Rhodesia (now Zimbabwe) and Nigeria demonstrating European efforts at promoting African art in workshops (p. 452). In order to deepen understanding of art history and relate it to African art, a museum was established to provide additional learning experience. The Art Department and its staff were later transferred to Kumasi in 1952 to form the nucleus of the Kumasi College of Technology. By 1958, the Specialist Training College, Winneba (which was later submerged into the University of Education, Winneba, UEW) had been established to train secondary school teachers in subjects including art and crafts. The Kumasi College of Technology became Kwame Nkrumah University of Science and Technology, KNUST, in 1961/62 ${ }^{1}$ and the art school became a College of Art in 1964 (Labi, 2013a, p. 19) now the Faculty of Art under the College of Art and Built Environment. Dogbe (2015), a pioneer of the African art course, narrates that art history was taught as part of the Design and General Art Studies Department courses when the college was established.

At the time the College was established, scholarships for graduate training abroad were limited to studio artists and students of art education, with little consideration for students of African Art History. Therefore, while studio art developed at the tertiary level, African Art History did not grow into an independent discipline, a fact that accounts for the rather modest critical contributions to its scholarship.

Rasheed Araeen (2005) conveys his concern about the lack of intellectual participation in art by Africans and encourages Africans to engage in a more rigorous discourse with theoretical underpinning (p. 417). Araeen cites the lack of recognition of

1 Kwame Nkrumah University of Science and Technology, Kumasi, Early history.

Retrieved from https://en.wikipedia.org/wiki/Kwame_Nkrumah_University_of_

Science_and_Technology. Accessed $26^{\text {th }}$ March 2016. University History. Retrieved from https://www.knust.edu.gh/about/knust/history. Accessed 26th March 2016. 
the works of prominent African artists and points to Africans lacking in their own intellectual resources and scholars, and therefore unable to conduct their own research and engage in knowledge production, which would provide a framework capable of interpreting the works of artists (p. 413). Araeen was referring to the works of prominent African artists such as the South African Ernest Mancoba's Composition (1940) (p. 417) as an example of the neglect of African artists' contribution to global art studies. Similarly, the works of Ghanaian artists, such as Amon Kotei, Oku Ampofo and Kobina Bucknor, have received inadequate scholarly attention except scanty information in exhibition catalogues and brief mention in studies on Ghanaian contemporary art. This illustrates Araeen's concern of lack of requisite capacity to conduct intellectual enquiries on Africa's art and artists by African scholars.

A survey of 193 publications comprising books (excluding e-books), journal articles and exhibition catalogues devoted to Ghana's art, written in English between 1927 and 2014 available in University of Ghana libraries and in Labi's personal collection, revealed interesting results. ${ }^{3}$ Of these publications, 143 (74.9\%) were by non-indigenes, while fifty entries, making $25.9 \%$, are by Ghanaian writers. Out of these 193 publications, 72 were books and the remaining 121 comprised chapters in books, which had references to Ghana's art, catalogues and articles. Forty-three of the writers of these 72 books were non-indigenous ${ }^{4}$ authors making $59.72 \%$ and 29 entries by local scholars in the form of books, book chapters and catalogues making $40.2 \%$.

Another survey of African Arts, from 1967 to Issue 2, 2015 provided 121 articles on Ghana's arts. Ghanaians wrote $18(14.8 \%)$ of the articles, while 103 making $85.1 \%$ were written by non-Ghanaians. This sample of a paltry Ghanaian contribution provides evidence supportive of Araeen's assertion of Africans not engaging enough in art knowledge production.

A comprehensive study of the literature would have considered other resources available locally and abroad, including primary sources written in different European languages, accounts on Ghanaian art from different disciplines, e-books and online journals and exhibition catalogues. This survey is therefore by no means comprehensive

3 The survey was by an examination of publications in the available collection that had any aspect of Ghanaian art in its content, chapters in books that discuss Ghanaian art and reviewing these works to establish the authors, background, methodology, content, themes and trends in the scholarship.

$4 \quad$ People not having either parents as Ghanaians, no Ghanaian ancestry or cultural and historical ties to the country and its culture. 
as there are works available abroad but not accessible to the author. The survey excluded archival and primary sources that have sections on art. It does not include selfpublications, newspaper articles nor student theses. It also discounts Internet sources not linked to a peer review journal or book.

Additional information has been derived from a questionnaire administered in May 2015 whose answers assist in understanding the concerns of this paper, which is the paucity of Ghanaian scholarly art contribution. As a result, this work benefits from the answers to about fifty questionnaires on art studies and scholarship. These were distributed to faculty in art studies, past and current art students in the three tertiary institutions (namely Kwame Nkrumah University of Science and Technology. University of Ghana and University of Education, Winneba), seeking their views on art studies and publications by Ghanaian scholars. There were visits and conversations at bookstores and the Artist Alliance gallery in Accra. The resources also included conversations I had with Zagba Oyortey, Director of the Ghana Museums and Monuments Board, GMMB (2013), when I was developing the $\mathrm{PhD}$ programme in Art History for the Institute of African Studies. The other discussions were with Dogbe (2015) and Ato Delaquis (2015), both retired lecturers, and Steve Kquofi, Head of Department of General Art Studies. The lecturers and Head of Department at UEW instead directed me to speak to Isaac OpokuMensah, the immediate past Head of Department who teaches art history. The questionnaire and conversations among several things sought to inquire about their understanding of what art history is and its future, if they know of or have read any art publication (book or journal article) by a Ghanaian scholar, and what their views are on the future of the discipline. Visits and interviews at the bookstores and galleries were helpful with regard to stocks and sales of art history books. In the bookstore at UEW, I was informed some lecturers preferred to sell their books (self-published) directly to students, and in KNUST some staff publications were sold in bookshops outside the university. However, the Artists Alliance gallery has art books, with a dominant foreign authorship, and some of the gallery's exhibition catalogues for sale.

Similarly, there is an occasional Ghanaian presence at international African art conferences and symposia. During some of these recent conferences, such as College Art Association's, CAA, 98th Annual Conference, Chicago (2010), there was one Ghanaian who presented a paper. The 15th Arts Council of the African Studies Association, ACASA, Symposium (2011) in Los Angeles had two Ghanaians presenting papers. The 16th ACASA Symposia (2014) had one Ghanaian presenting a paper, but none at the South African Visual Arts Historians (SAVAH) conference in South Africa (2011). The same absence applied to the 2015 European Conference on African Studies, ECAS, held in Paris. Ghanaian art scholars' presence is also rare at art panels of the African Studies Association, ASA. It seems that this situation has not improved since John Drewal's 
(1990) observation that European and American scholars have been at the forefront of African art studies (p. 38).

\section{Ghana's Art Scholarship}

Since the emergence of African art history as an academic discipline in the 1950s, studies of Ghana's art have produced insights from adaptations of models from different disciplines, including art, anthropology, archaeology and history. A careful selection of the literature has been applied to original research and the most relevant and representative of the publications are discussed below.

A pioneer among Ghana's art writers was Rattray (1923/1927) who made significant contribution. Similar anthropological contributions are by the Ghanaian- born Alexander Kyerematen. His works include 'Regalia for an Ashanti durbar' (1961). The most significant of Kyerematen's works are the photographs he took and the script he wrote when commissioned by the government to mount an exhibition for Queen Elizabeth II's visit in 1959 and published in 1964. He co-authored one article with Allen Bassing (1972) and published his last known work in 1977.

The eclectic methodology ${ }^{5}$ in the mid-twentieth century prompted scholars from diverse backgrounds to participate in this new endeavour. These initial methods were a swing between a poor account of history, weak ethnography or a combination of the two. Many early scholars saw themselves as anthropologists rather than art historians, and perceived the art being learned as a reflection in the progress of the material culture of the people they studied (Willet, 1971, p. 30). Later, scholars including sociologists, art historians and museum curators with different perspectives emerged, applying new methodologies and theories to their inquiry. There has since been a break from the ethnographic approach as there is now a palpable commitment to art history. Some scholars have explored topics such as aesthetics, iconography, performance, philosophy and style, and conducted in-depth studies, synthesized information and developed the scholarship further as a result of interdisciplinary perspectives.

Between the early works the Ghanaian writers, Kofi Antubam (1961/1963), Kyerematen and Kojo Fosu (1986), there has been remarkable progress in methodologies and themes advanced largely by Euro-American academics. In the decades that followed up to the end of the twentieth century, new Ghanaian scholars, including Alfred Quarcoo, a sociologist, Kwame Anthony Appiah, a philosopher, Nii Quarcoopome, an archaeologist, Atta Kwami, a painter, and Kwame Labi, an art historian, have contributed

$5 \quad$ A theory and practice that selects and gathers doctrines, perspectives or styles from various sources including anthropology, history, and archaeology depending on what appears to be most useful for a particular use (Drewal, 1990, p. 32). 
to the discipline. The Research Review has published articles on Ghana's art studies with Quarcoo, Labi and Ohene-Konadu (1994) among the contributors.

In 1979, African Arts dedicated a special issue to the study of art in Ghana with no local scholar contributing. In that issue, Cole (1979) points to the number of scholars who, from diverse backgrounds are developing, refining historical analysis, identifying styles, elucidating symbolic systems and pushing the boundaries of aesthetic knowledge (p. 26). The articles provided detailed explorations of other art forms, which aimed to reflect the omissions and shortcomings of the 1977 exhibition catalogue, which he co-published with Ross. Among the new tools discussed was the use of photography to capture local values, aesthetics, moments and events. Cole and Ross (1985) and Jenkins and Geary (1985) later investigated the use of photographs as important resources to art studies but a more detailed and systematic approach is by Wendl (2001), who problematises photography as an aesthetic form or a cultural phenomenon in anthropology. Arlt and Quarcoopome (2009) later remind us that traditional leaders used photographs to negotiate their place and integration into the colony, and within the doctrines of the church (p. 62).

Antubam (1963) sets the pace in Ghanaian aesthetics by providing the main characteristics of Ghanaian art and culture, in an attempt at Ghanaian aesthetics. This paved the way for extensive attention to Akan aesthetics and world view through the works of Silver (1983), and Warren and Andrews (1977). Other studies include how the Gurensi express aesthetic judgments through wall paintings, pottery and facial decorations (Smith, 1978, p. 36-41). Gott (2007) takes advantage of the strong appetite for fashion among the Asante and demonstrates how they make a 'show', even at the demise of a husband or close relative, through the strategies employed and dynamics of funerary presentations (p. 79-106). Gott's (2010) work on Ghanaian kaba introduces a new genre in fashion.

Cole and Ross (1977) point to a dynamic culture of influence, particularly Islam from the north and European from the south, on Akan art. Prussin (1980) supports this as important in understanding Asante architectural history. Preston (1975), Ross (1979/2007) and Labi (2006) have also discussed European influences on Fante art and architecture while Hess (2006b) introduces the modern and postcolonial political strategies in the development of architectural styles. While these scholars diversify the studies, the Ghanaian architect Wellington's (2011/2012) studies on Accra's heritage after contacts with the Danes have appeared in the literature.

Among the Gurensi, architectural construction and space are gendered. Gender differentiation, complementarity and decoration between the compound entrance and within it show gender relations (Smith, 1986). Later Smith (1989) investigated the relationship between the earth and women's pots in Gurensi as an important element in social harmony. 
Art historians have now found it imperative to pay attention to local artists and their study now engage scholarly attention. Pioneering in this were Antubam's studies on Osei Bonsu, one of the greatest Ghanaian sculptors. After Antubam, Fagg (1968) was one of the first European art historians to recognise the contribution of Bonsu to the study of Ghana's art history. Recent writers, including Andrews and Warren, and Ross (1984) have consulted him on a wide range of issues. The art of Vincent Kofi, Ablade Glover, Ato Delaquis and others have prompted the study of contemporary Ghanaian artists as an area of inquiry. Those in the Diaspora such as El Anatsui and Kwesi Owusu-Ankomah have attracted art historians to their works because of their combination of inspirations from Ghanaian imagery and foreign influences. Ross' (2001) study of the works of George Hughes is an example of this interest.

Akan art is rich in communicative aspects. Ross (1977b/1982) has applied iconography to its study, and Cole and Ross (1977) have used the expression 'verbalvisual nexus' to illustrate the interconnectedness between Akan imagery and proverbial sayings. Ross (1977b/1982) and Patton (1984) later traced the origins of some of these works by exploring early European primary sources in explaining the different iconographic types and works, uses and their meanings. However, Malcolm McLeod (1976) warns us not to classify all Akan or Ghanaian art as symbolic as he distinguishes sculpture that has verbal components from the genre that does not (p. 90). Labi's (2002b/2009) studies on the relationship between Fante flag symbols, proverbs and their interpretations by rival companies and intangible aspects of Akan art broaden the study. Metaphors are part of Asante communicative strategies but the challenges of transmission of this knowledge and collective memory raises important issues associated with the fluidity of these narratives (Owusu-Sarpong, 2003, pp. 239-240).

After Field's (1948) study, Gilbert's three works Ewe funerary sculpture (1981), Mystical protection among the Anlo-Ewe (1982), Akan terracotta heads: God or ancestors? (1989a) and Sources of power in Akuropon-Akuapem: ambiguities in classifications (1989b), follow the trajectory of the use of clay pointing out the need to contextualize pottery, as they have moral implications. She warns against lumping all terracotta from Ghana into one category, or seeing them as unconnected to another. Her works reveal that despite modernisation and social change, traditional representation of mystical powers in clay and cement figures is still important among the Anlo-Ewe (Gilbert, 1982). Bonakire pottery making has also been fairly recounted by Berns (2007) providing a rich context for the study of integration of pottery production, its consumption and distribution. However, for Aronson (2007) pottery also provides important components for domestic and ritual vodun (p, 80-85).

Following Rattray's earlier account of brass casting, the subject has subsequently attracted foreign interest and the cire perdue technique used in its manufacture, has been examined by Dark (1973) as a sub-regional technique. Garrard made insightful 
contributions in a collection of essays between 1972 and 1973, culminating in his 1980 book Akan weights and the gold trade. He sets himself the task of constructing the history of Akan brass casting, and following these series of publications was what may be considered a sequel (Ross \& Garrard 1983) to similar studies in the Arts of Ghana. The 1983 work was firmly grounded in a scientific approach built upon archaeological evidence and a meticulous examination of sources and cast brass leading to informed speculation. In 1986, Ray Silverman, examined Bono cire perdue technology, and Christine Fox provided insights into the Akan technique of modelling figures and animals for casting. Garrard (1984) extended his investigation to Akan silver (pp. 48-53).

It was not until the last quarter of the twentieth century when Fosu (1986) wrote on contemporary art in Africa, citing some Ghanaian modern and contemporary artists. Other studies have been on the dynamics and aesthetic satisfaction in visual innovations in Ghana's cities in the postcolonial era, where many unskilled people coming from the countryside are confronted with the challenges of modernity. These cities have become centres for cross-fertilization of ideas and artistic expressions appropriating American icons, and other influences through hairstyles and thought-provoking creative art on trotro, ${ }^{6}$ mini-buses, studio backdrops and a wide range of other imaginative compositions depicted in urban street art (Quarcoopome, 2009). Other works that explore these artists and their genres include Chernoff (1977), Kristen (1980), Falgayrettes-Leveau (2003) and Ross (2014a/2014b). Recent works of Hess (2006a), Kwami (2003/2012), Labi (2013a), and Woets (2014) have contributed to the studies on Ghana's modern and contemporary art.

Early sources for the discipline included exhibitions and accompanying catalogues, starting in 1956 with the foreword by Arthur Lindsey and another by Antubam (1961). The catalogue by Cole and Ross (1977) may be referred to as the most comprehensive historical account on Ghana's art. The Ghana: yesterday and today (Owusu-Sarpong \& Falgayrettes-Leveau, Eds., 2003) catalogue addresses Ghana's art traditions, its modernity and receptiveness to other cultures, contemporary and popular art, changes and persistence in its essays including three by the Ghanaian scholars, Quarcoopome, Anquandah and Kwami. Some recent catalogues (Fosu, 2004/2009) focus on Ghanaian contemporary art in a modern world, while those by Labi (1992/2000), and Labi and Boachie-Ansah (2008) are on traditional art.

For the first time in the history of the Museum of Modern Art, New York, a mobile exhibition (2010) was dedicated to the works of the Ghanaian-born El Anatsui, resident in Nigeria, an indication of the recognition of Ghana's contemporary art and the

\footnotetext{
6 A name derived from the two and a half pence coin called 'tro' charged as fare by passenger vehicles in the 1950s and early 1960s operating in the city as commuter vehicles and has been maintined to date.
} 
global contribution of Anatsui. The four essays by Olu Oguibe, Chika Okeke-Agulu, Robert Storr and Appiah, in the catalogue (Binder Ed., 2010), discuss the early years of Anatsui's work and demonstrate the changes in style and materials in his sculpture.

The pioneer Ghanaian contributors on performance were Awoonor-Williams (1967a/1967b), de Graft (1968a/1968b), Bame (1968) and Acquaye (1968). After these early works, studies on performance such as the Sisala masquerades by Nunley (1977, pp. 58-64), masquerading among the Grusi and Manding (Bravmann 1979), and Smith's (1982) studies on the Frafra and Gurensi have been done. The visual and performing arts that accompany Frafra funerals, Smith (1987) explains, highlight the social roles of funerals in honouring the deceased, and revitalising ties between the living and ancestors. Scholars are continuing to study performance such as Micots (2012/2014).

The literature suggests a dynamic scholarship on the breadth of Ghanaian art within and across genres in secular and non-secular settings. The investigative methods used highlight the similarities and differences among the various ethnic groups with respect to form and sources of influence. The artists' creativity, responses to modernity, technology and materials manifest in these publications. Also highlighted are the works of the few local scholars and the leadership of foreign scholars in these investigations.

\section{Ghana's Art Studies: Its State and Challenges}

The discussion that follows is guided by the problem of minimal Ghanaian scholarly contribution and the concerns raised by Araeen and Drewal. One of the questions in the questionnaire was 'There is abundant literature on Ghanaian art. Unfortunately, a survey of the authors is largely non-Ghanaian. Can you give me the reasons for this?' The respondents gave various reasons, including lack of interest and capacity. E. K. Howard, a lecturer at KNUST, says 'European authors seem to be more interested in issues pertaining to African art and customs. Ghanaians are not much enthused with their own culture ...' This summarises the low patronage of the study of Ghanaian art. Lorraine Osewele (2015), a past student in art history, provides further explanation to Howard's answer saying: 'I think non-Ghanaians are more interested in doing research on Ghanaian art than Ghanaians themselves - perhaps non-Ghanaians are better resourced or perhaps Ghanaians underestimate their arts value'. These two responses sum up some of the reasons for the status quo. Edwin Bodjawah, a lecturer in contemporary art at the College of Art, says, 'There is a huge gap between what is happening in the art world and what is being done here'. He admits a knowledge gap between what is being done elsewhere and what pertains in Ghana's tertiary institutions. These differences include lack of specialists, how theoretical frameworks are taught and used and the application of established art history methodologies to research. The difference also relates to availability of local art journals, galleries and museums, a critical 
mass to patronise the outcomes of research, connoisseurs, foundations to provide funding and lack of governmental support.

Some of these challenges may be explained through the account of how the College of Art's art history course was developed. The present African Art and Culture course started in 1973 as African art when an English student, Ms. Clement Taylor, enrolled in the Master of Arts programme in African art. John Bull, a British sculptor and lecturer in African art, was tasked to write an M.A. course in African art for this student. Subsequently, Chuke Amefuna, J. J. Clement Hagan and Dogbe were admitted as the first African art students (1974 to 1976). Dogbe later received his doctorate, and by his return the M.A. course had been firmly established in the Department.

Bull's interest was in African art and that of Osei-Agyeman, a Ghanaian colleague of Bull, was in culture, as both lecturers had no training in African art history. This biased their teachings towards African art and culture. Their advocacy in teaching this was to attract foreign students, particularly African-American students. There was later a proposal to change the course from African art to African art and culture. ${ }^{7}$ The document maintained that, 'This will surely enable Ghana especially this university to earn more foreign exchange' (2001, p. 3). With the gradual reduction in government subvention and foreign students paying fees in foreign currency, it became attractive to the university while the foreign students found a novel African art course outside Europe and America to study. When I enquired from Kquofi (2015) about the College's plan to develop African art history, he admitted that a proposal had been submitted for an Art History Department to be established. Although the challenge was inadequacy of faculty, the Department of General Art Studies has been training local staff as well as receiving applications for new faculty. The challenge will be if the proposed Department of Art History would address the current problem under discussion.

At UEW, the situation is not much different as art history is taught for one semester only to first year students, according to Opoku-Mensah (2015). The focus of teaching art history is to train teachers to teach aspects of art history in General Knowledge in Art in Senior High Schools. At the M. Phil. Level, there is a course called the Arts of Ghana, which covers theatre, music, and pre-historic to contemporary art, which is a combination of visual and performing arts.

The responses to the questionnaire represent an unfortunate attitude towards art history as they suggest it is only Europeans and Americans who are interested in studying the art of Ghana. Howard (2015) makes an interesting remark about studio artists, saying '[a]rtists find it difficult to publish as writing is a skill that one has to develop. The trend is changing now as most artists are now publishing'. On the contrary, Delaquis (2015)

7 Proposal to change the title of the 'African art' to 'African art and culture' by the Department of art history, was approved by the College of Art in 2001. 
declared he was disappointed at the contents of the African art and culture course. His reason is that he does not see the impact of such art students on art. He says, 'There are hundreds of these students but [they can] not produce simple articles in newspapers' or journal articles. Are the faculty and students therefore unable to engage in scholarship, and meet the rigour demanded by journals and publishing houses? The concerns of some graduate students about the faculty are echoed thus 'They are not committed to the studying of their art or the need to have new outcomes following from refreshed perspectives of their art ...' says one of the respondents. Other responses can be summarised as no motivation and encouragement to write. The students expressed other sentiments such as 'failure of Ghanaian educational institutions (especially tertiary institutions) to provide adequate opportunities for students to study art and art history', says another respondent, a graduate student at the Institute of African Studies. The unavailability of relevant books and resources in the University of Ghana online database and access to online art journals are some of other challenges faced by Ghanaian graduate students of art.

The other problems are restrictions placed on some African addresses by credit card companies disallowing payments from, and shipments to these addresses, or no shipments outside Europe or the US. While this is true, an answer to the question 'How would you suggest resources can be improved' was that universities should subscribe to art journals and purchase current literature on art history. The University of Ghana continues to acquire current literature, though this may be inadequate.

The other question that yielded interesting responses was 'Can you give me the names of Ghanaian writers who have published on Ghanaian art in refereed journals and books?' It appears that knowledge of such authors is limited to Antubam, Fosu, Kwami, Akwasi Sarpong and E. V. Asihene though a few also cited Quarcoopome and Labi. Respondents from each university cited the publications of their lecturers. Respondents from the College of Art cited Karikacha Seidu, Steve Kquofi and Ibrahim Mahama Seidou as scholars who have published in international journals. I decided to search electronically using Google, Jstor and eLibrary USA without any success. Even then, these local publications were difficult to find in local bookstores and libraries. In my discussion with Kquofi, he admitted that some of his publications sold in the bookstores were not peer reviewed. I spent some time at the UEW with Adolph Agbeh, the Acting Deputy Librarian, searching for publications of faculty in the library and online publications. This was difficult and confirmed what Patience Sersah, a UEW Senior Stores Superintendent at the bookstore told me, i.e. that lecturers prefer to sell their books (self-publications) directly to the students, to leaving copies in the library.

Some of the respondents admit good prospects for art studies and suggest making it compulsory at the undergraduate level to generate interest. This, hopefully should impact positively students' understanding and appreciation of art, and ensure further 
training for students. Additionally, it would broaden the range of courses available to students and create a critical mass for the establishment of art history departments. The Institute of African Studies offers art history courses as part of a general African Studies programme to second year undergraduate students, M.A. and PhD students. However, this is inadequate for specialisation in African art history.

It is evident that there is a need to train art historians and not assume artists who teach studio courses can accidentally acquire the knowledge to teach art history. There needs to be a paradigm shift and a disavowal of the assumption that art history can only be taught in art colleges and that only studio art students can offer such courses. Finally, there is the need to create avenues for dissemination of research findings, create a professional association and encourage national dialogues to discuss the promotion of the discipline. Collaborative works, funding for research and scholarships are prerequisites to advance the discipline. It is amply clear from the above discussion that African art history is not developed in the country's tertiary institutions.

\section{The Future of the Discipline}

The historical account of Ghana's art and the central role it plays have consistently featured in narratives and written records. What is absent is its comprehensive academic study and specialisation at higher degrees. In 1963 therefore, during the inauguration of the Institute of African Studies, the President of the Republic, Kwame Nkrumah's speech 'African Genius,' gave a clear suggestion on how to conduct research into Africa's past in order to develop models for scholars to pursue a new and aggressive Afrocentric approach to artistic inquiry. He stated that appreciation of African art should be more than a simple curiosity but pave the way towards the understanding of the African and his or her art (Botwe-Asamoah 2005, p. 65). In his opinion, the admiration of African art should be something not just for novelty, but also for enhancing understanding and respect for Africans, shedding light on African art, and positioning it within global artistic traditions and scholarly discourses (Botwe-Asamoah, 2005, p. 65). The facilities at the Institute included an ethnographic museum (Fig. 2) to promote the teaching of the African visual art. 


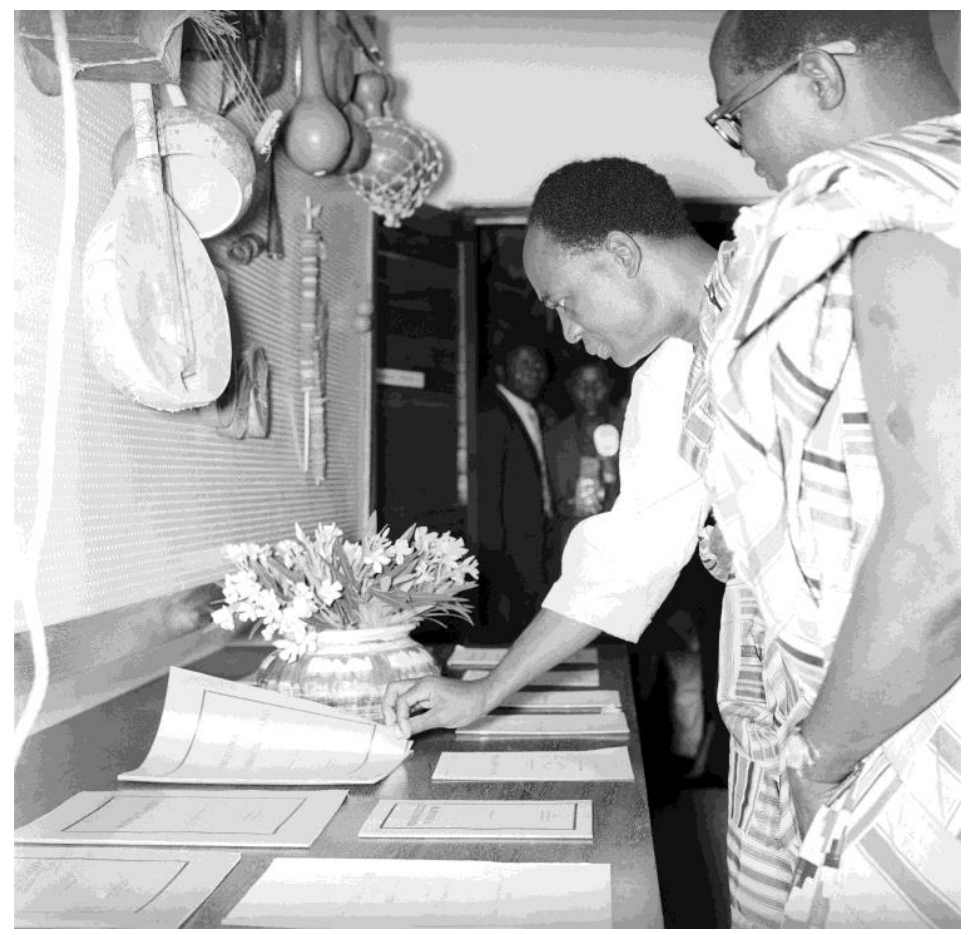

Fig. 2. Kwame Nkrumah in 1963 being conducted round the IAS facilities by J. H. Kwabena Nketia, in the foreground of photo, On the top left is the display of some musical instruments as part of the ethnographic collection. Photo: courtesy of IAS audio visual section.

Unfortunately, art studies in Ghana deal with a limited range of art history topics taught at the undergraduate and graduate levels to the neglect of the broader subject and its theoretical and methodological underpinnings of critical enquiry. The revised 1987 second cycle curricula introduced limited teaching of a general knowledge in art, which stimulated the publication of amateur second cycle school art books. Though this is significant to the development of the discipline, these books require a body to review their contents and illustrations.

There is a re-emerging local interest in writing about Ghana's art, which is gradually re-appearing in the form of articles, exhibition catalogues, brochures and texts on the Internet. The subject will benefit from improved scrutiny, wider circulation of published works and media support. A review of courses to consider current trends in the 
discipline, set standards and orientation is critical at this point. Interactions and exchanges with institutions and colleagues who have experience in teaching African art history will be of immense benefit. Joint research projects or collaborations with local institutions and scholars, cross-border projects in the sub-region to trace origins, histories, artistic styles and influences will surely strengthen sub-regional capacity. These, I believe, will lead to increased discourse in schools and on university campuses. Equally critical for sustained interest in the discipline are the formation of strong subject associations and the organisation of symposia, conferences and travels. Research by Ghanaian scholars from diverse backgrounds, will lead to new approaches, definitions and terminologies taking into consideration language, myths, beliefs, inputs from traditional leaders, custodians as well as the voices of indigenous artists. This will gradually lead to increase in local perspectives and enrich the discourse.

In the late 1950s and the 1970s the GMMB was at the forefront of providing a platform for exhibitions and for artists such as Antubam and Bucknor to engage with the public through lectures. Several exhibitions have since been held there to promote art. To enhance its contribution to the discipline, GMMB must improve accessibility to its collections, enhance information on the objects, provide high-resolution digital images of the collection and establish an efficient retrieval system. Additionally, the GMMB must strengthen its research and have a budget and personnel to conduct original research and disseminate its findings, through publications, exhibitions and educational programmes. Collaborations with institutions in research, curriculum development, internships and educational activities will improve the museum's contribution to the study than its current strategy of mainly providing exhibition space. The GMMB must address current challenges and interests; be at the forefront of debates; and provide the space for this as it had previously done in the late 1950s and early 1970s.

In a discussion with Oyortey (2013), he agreed to offer the museum's expertise in the experiential learning component of the programme. This joint training component of the students training is expected to expose students to practical experience and to bring them into close contact with users and patrons of art, and how to respond to the needs of art lovers, the public and scholars in order to develop the discipline.

\section{Conclusion}

A team of researchers from IAS were reminded in the court of the Asantehene, (king of the Asante ethnic group), in $2001^{8}$ about how important Rattray's work and the IAS stool histories have become major resources in traditional governance and in the

8 This was during a courtesy call on Otumfuo Osei Tutu II to formally seek permission from and inform him of the Institute of African Studies intended research on the death, burial and funeral rites of the late Otumfuo Opoku Ware II. 
settlement of disputes in the court. The IAS was thus told of how imperative it is to pursue research on Ghana's art and traditions. Kyerematen's works were, in effect, the beginning of the process of documenting and writing about Ghana's art and regalia. The importance of such local studies was highlighted in 2003, when the World Bank initiated a partnership with the Asanteman Council in a development programme called Promoting Partnership with Traditional Authorities Project (PPTAP) with a grant of US\$4.5 million awarded through the Ghana government. It included a component to develop local communities through identification and documentation of Asante heritage assets and how these can be used for local development (Boachie, Labi \& Brempong 2009). Such initiatives have placed art as an integral part of community development. The purchase of Akan cast brass works (Figs. 3a-b) ${ }^{i}$ by the late Chancellor of the University of Ghana, Oyeeman Nana Wereko Ampem II, its donation to UG and subsequent research conducted on Akan brass works, a permanent exhibition of the collection and subsequent publications should serve as an example of the use of art in an integrated manner.

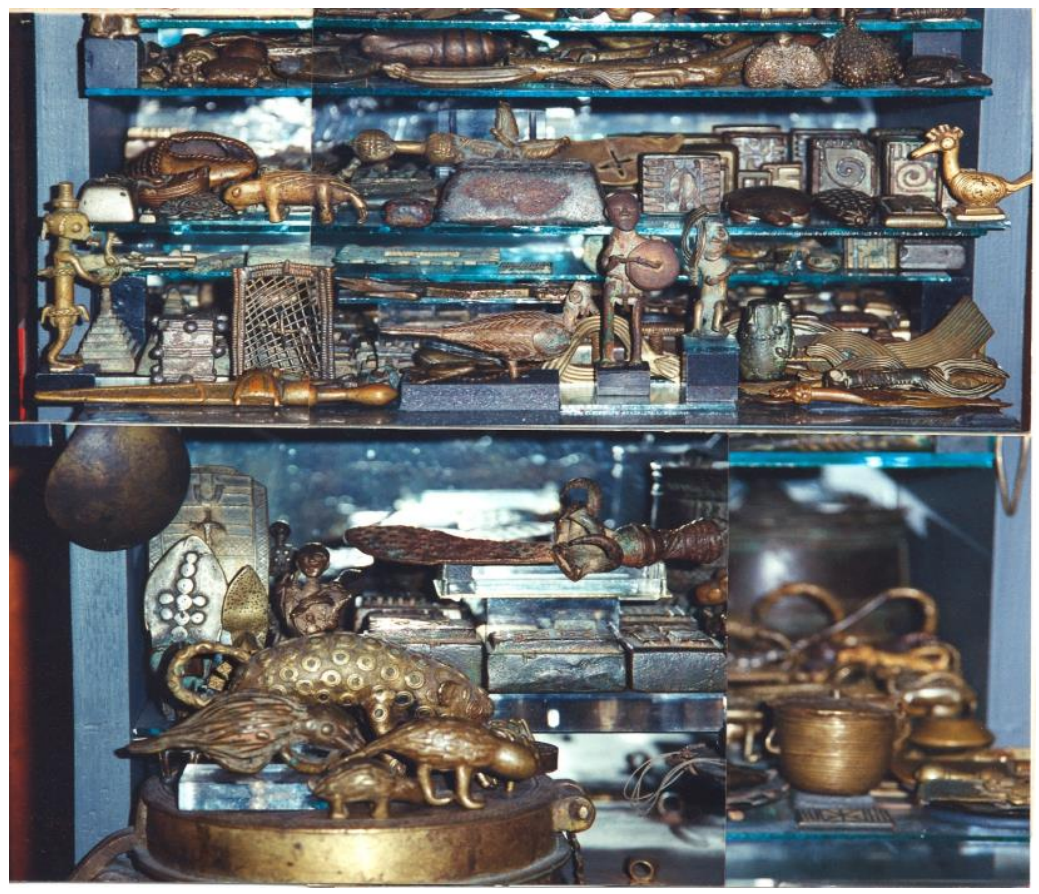

Fig. 3a. This photograph shows how the owner of the collection, Mr. Dieter Röttger, stored the brass works. 


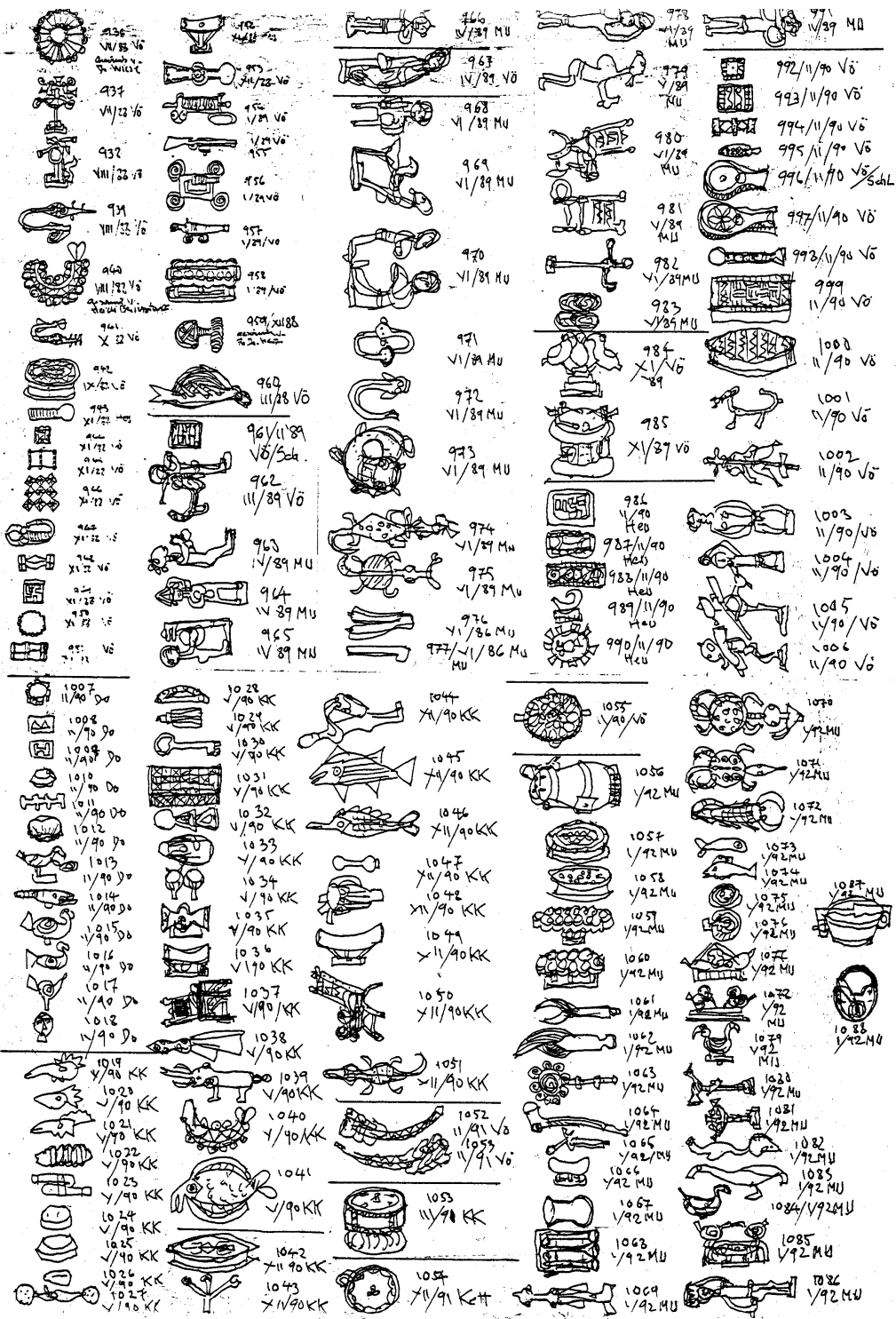

Fig. 3b. This photograph shows drawings and documentation of the collection by Mr. Dieter Röttger. 
The current faculty, students and other scholars have to challenge themselves with innovative methodologies, revise existing course content, specialise, forge partnerships and collaborations locally and externally, provide teaching aids, lobby for scholarships and seek research grants for Ghanaian-led investigations. The approach to art studies must be multi-sectoral and multi-disciplinary, and should involve private and public partnerships, local and external funding; it should also undertake new collections and exhibitions, seek to integrate technology and social media into research. All of these should be useful tools for the new direction for art studies in Ghana. 


\section{References}

Achimota review 1927-1937. (1937). Accra, Ghana: Achimota Press.

Acquaye, S. (1968). The language problem of the developing African theatre drama/performance. African Arts, 2, (1), 58-59.

Antubam, K. (1963). Ghana's heritage of culture. Leipzig, Germany: Koehler and Amelang.

Antubam, K. (1961). Ghana's arts and crafts. Accra, Ghana: GNTC.

Appiah, K. A. (2010). Discovering El Anatsui. In L. M. Binder (Ed.), El Anatsui: When I last wrote to you about Africa (pp. 63-75). New York, NY: Museum of African Art.

Araeen, R. (2005). Modernity, modernism, and Africa's place in the history of art of our age. Third Text, 19 (4), 417.

Arlt, V., \& Quarcoopome, N. O. (2009). Photography, European emblems and statecraft in Manya Krobo (Ghana), about 1860-1939. In S. H. Larsen (Ed.), Through African eyes: The European in African art (pp. 61-74). Detroit, MI: Detroit Institute of Arts.

Aronson, L. (2007). Ewe ceramics as the visualization of vodun. African Arts, 40 (1), 80 85.

Awoonor-Williams, G. (1967a). A dirge. African Arts, 1 (1), 50-50.

Awoonor-Williams, G. (1967b). Night of my blood. African Arts, 1 (1), 50-51.

Bame, K. N. (1968). Comic play in Ghana. African Arts, 1 (4), 30-36.

Barbot, J. (1732, 1992). A description of the coast of north and south Guinea (Vol. II). P. E. Hair (Ed.), London, UK: Hakluyt Society.

Bassing, A., \& Kyerematen, A. A. Y. (1972). The enstoolment of an Asantehene. African Arts, 5 (3), 28-31.

Berns, M. C. (2007). Pottery making in Bonakire, Ghana. African Arts, 40 (1), 86-91.

Binder, L. M. (Ed.). (2010). El Anatsui: when I last wrote to you about Africa. New York, NY: Museum of African Art.

Blier, S. P. (1990). African art studies at the crossroads: An American perspective. In R. Sieber (Ed.), African studies: The state of the discipline (pp. 91-107). Washington, DC: Smithsonian Institution.

Boachie, A. B., Labi, K. A., \& Osei Tutu, B. (2009). Promoting partnership with traditional authorities in the identification and development of cultural heritage: An Asanteman-World Bank initiative in Ghana. Africa Today, 55 (4), 2-26.

Bosman, W. (1967). A new description of the Cold Coast of Guinea. London, UK: Frank Cass and Company. ( Original work published 1705)

Botwe-Asamoah, K. (2005). Kwame Nrumah's politico-cultural thought and policies: an African centred paradigm for the second phase of the African revolution. New York, NY: Routledge. 
Bravmann, R. A. (1979). Gur and Manding masquerades in Ghana. African Arts, 13 (1), 44-51.

Chernoff, M. J. (1977). Andrew Ofori Danso of Ghana. African Arts, 10 (3), 32-35.

Cole, H. M. (1979). Art studies in Ghana. African Arts, 1 (13), 26-27.

Cole, H. M., \& Ross, D. H. (1985). The art and technology of field photograpy. African Arts, 18 (4), 46-51.

Cole, H. M., \& Ross, D. H. (1977). The arts of Ghana. Los Angeles, CA: University of California.

Coe, C. (2002). Educating an African leadership: Achimota and the teaching of African culture in the Gold Coast. Africa Today, 49 (3), 23-44.

Courtnay, M. (2014). Carnival in Ghana: Fancy dress street parades and competition. African Arts, 47 (1), 30-41.

Courtnay, M. (2012). Performing ferocity: Fancy dress, asafo, and Red Indians in Ghana. African Arts, 45 (2), 24-35.

Dark, P. J. C. (1973). Brass casting in West Africa. African Arts, 4 (4), 50-53.

de Graft, J. C. (1968a). The old sea chain. African Arts, 1 (2), 46-47.

de Graft, J. C. (1968b). Death of the mahogany. African Arts, 1 (2), 46-46.

Drewal, H. J. (1990). African art studies today. In R. Sieber (Ed.), African studies: the state of the discipline. Washington, DC: Smithsonian Institution.

Fagg, W. (1968). African tribal images. Cleveland, OH: The Katherine Fischer Reswick Collection.

Falgayrettes-Leveau, C. (2003). Almighty God, the inspired artist. In C. Owusu-Sarpong $\&$ C. Falgayrettes-Leveau (Eds.). Ghana hier et aujourd'hui-yesterday and today (pp. 335-352. Paris, France: Museé Dapper.

Falgayrettes-Leveau, C. and Owusu-Sarpong C. (Eds.) (2003). Ghana: Yesterday and today. Paris, France: Museé Dapper.

Field, M. J. (1948). Akim-Kotoku, an oman of the Gold Coast. London, UK: The Crown Agents for the Colonies.

Fosu, K. (1986). 20th century art of Africa. Zaria, Nigeria: Gaskiya Corporation Ltd.

Fosu, K. (2004). Contemporary art in Ghana, Transitions: Samtidskunst Fra Ghana. Copenhagan, Denmark: Ulandssekreariantet.

Fosu, K. (2009). Pioneers of contemporary Ghanaian art. Accra, Ghana: Type Company Ltd.

Fox, C. (1986). Ashante brass casting. African Arts, 19 (4), 66-71.

Garrard, T. F. (1972a). Studies in Akan goldweights: (I) the origin of the goldweight system. Transactions of the historical society of Ghana, 13 (1), 1-20.

Garrard, T. F. (1972b). Studies in Akan goldweights: (II) the weight standards.

Transactions of the historical society of Ghana, 13 (2), 149-162. 
Garrard, T. F. (1973). Studies in Akan goldwieghts: weight standards. Transactions of the historical society of Ghana, 14 (1), 1-16.

Garrard, T. F. (1973a). Studies in Akan goldweights: (III) the weight names. Transactions of the historical society of Ghana, 14 (1), 1-16.

Garrard, T. F. (1973b). Studies in Akan goldweights: (IV) the dating of Akan goldweights. Transactions of the historical society of Ghana, 14 (2), 149-168.

Garrard, T. F. (1980). Akan weights and the gold trade. London, UK: Longman.

Garrard, T. F. (1980b). Brass in Akan society in the nineteenth century: A survey of the archaeological, ethnographic and historical evidence. (M.A. thesis). University of Ghana, Legon, Ghana.

Garrard, T. F. (1984). Akan silver. African Arts, 17 (2), 48-53.

Garrard, T. F. (2003). Akan metal art. Ghana: yesterday and today. Paris, France: Musée Dapper.

Gilbert, M. (1981). Ewe funerary sculpture. African Arts, 14 (4), 44-46.

Gilbert, M. (1982). Mystical protection among the Anlo-Ewe. African Arts, 15 (4), 6066.

Gilbert, M. (1989a). Akan terracotta heads: God or ancestors? African Arts, 22 (4), 3486.

Gilbert, M. (1989b). Sources of power in Akuropon-Akuapem: Ambiguities in classifications. In W. Arens, \& I. Karp (Eds.), Creativity of power: Cosmology and action in African Socities (pp. 59-90). Washington, DC: Smithsonian Institution.

Gott, S. (2010). The Ghanaian kaba: fashion that sustains culture. In S. Gott and K. Loughram (Eds.), Contemporary African fashion (pp. 11-27). Bloomington, IN: Indiana University Press.

Gott, S. (2007). "Onetouch" quality and "marriage silver cup": performative display, cosmopolitanism, and marital poatwa in Kumasi funerals. Africa Today, 79-106.

Hess, J. (2006a). Spectacular nation: Nkrumahist art and resistance iconography in the independence era. African Arts, 39 (1), 21.

Hess, J. (2006b). Art and architecture in postcolonial Africa. Jefferson, NC: McFarland and Company Inc.

Jenkins, P. \& Geary, C. (1985). Photographs from Africa in the Basel mission archive. African Arts, 18 (4), 56-63.

Kristen, C. (1980). Sign-painting in Ghana. African Arts, 13 (3), 38-41.

Kwami, A. (2012). Kumasi realism, 1951-2007, an African modernism. New York, NY: Columbia University Press.

Kwami, A. (2003). Ghanaian art in a time of change. In Christiane Owusu-Sarpong \& Christiane Falgayrettes-Leveau (Eds.), Ghana: yesterday and today (pp. 285319). Paris, France: Museé Dapper. 
Kyerematen, A. A. Y. (1961). Regalia for an Ashanti durbar. Kumasi, Ghana: Kwame Nkrumah University of Science and Technology Press

Kyerematen, A. A. Y. (1964). Panoply of Ghana: Ornamental art in Ghanaian tradition and culture. New York, NY: Frederick A. Praeger.

Kyerematen, A. A. Y. (1997). Durbar in honour of His Royal Highness, The Prince of Wales. Kumasi, Ghana: Dwabrem, Manhyia.

Labi, K. A. (1992). Institute of African Studies museum. Legon, Ghana: Institute of African Studies.

Labi, K. A. (2000). Asante kings of the twentieth century: Power, pomp and pageantry: continuity and change in Asante kingship. Legon, Ghana: Institute of African Studies.

Labi, K. A. (2002). Criminalizing art: The struggle between Fante asafo companies and the British administration on the Gold Coast (1844-1957). Baessler- Archiv, 50, $1-16$.

Labi, K. A. (2002b). Fante asafo flags of Abandze and Kormantse: A discourse between rivals. African Arts, 35 (4), 28-37.

Labi, K. A. (2006). Transformation of European forts, castles and flags into local Fante iconography. Research Review, 22 (1), 83-93.

Labi, K. A. (2009). Reading the intangible in tangible Akan art. International Journal for Intangible Heritage, 4, 41-57.

Labi, K. A. (2013a). Afro-Ghanaian influences in modern Ghanaian paintings. Journal of Art Historiography, 9, 1-23.

Labi, K. A., \& Boachie-Ansah, J. (2008). Kuduo: The Akan art of brass casting. Legon, Ghana: Institute of African Studies.

McLeod, M. (1976). Verbal elements in West African art. Venezia, Italy: Luglio, Associazione degli amici dell'arte extraeuropea.

Müller, W. (1983). Description of Fetu. In Adam Jones (Ed.), German sources for West African history 1599-1669. Wiesbaden, Germany: Steiner.

Nkrumah, K. (1963). Speech read at the opening ceremony of the Institute of African Studies, University of Ghana, Legon. Accra, Ghana: Afram Publications.

Nunley, J. W. (1977). Sikilen: Transformation of a Sisala masquerade. African Arts, 11 (1), 58-64.

Ohene-Konadu, K. (1994). The effects of kente \& adinkra industry in Kwabre district of Ashanti. Research Review, 10 (1 \& 2), 32-45.

Okeke-Agulu, C. (2006). Art history and globalization. In J. Elkins (Ed.), Is art history global? (pp. 202-207). New York, NY: Routledge.

Owuor-Anyumba H. Ngugi W. T., \& Lo Liyong T. (2010). On the abolition of the English department. In Vincent, B, Leitch (Ed.), The Norton anthology of theory and criticism (pp. 1995-2000). New York, NY: W. W. Norton and Company. 
Owusu-Sarpong C. (2003). From words to ritual objects. In C. Owusu-Sarpong \& C. Falgayrettes-Leveau (Eds.), Ghana: Yesterday and today (pp. 25-92). Paris, France: Museé Dapper.

Patton, S. F. 1984. The Asante umbrella. African Arts, 7 (3), 37-42.

Preston, G. N. (1975). Perseus and Medusa in African military art in Fanteland 18341972. African Arts, 8 (3), 36-41.

Prussin, L. (1980). Traditional Asante architecture. African Arts, 13 (2), 57-87.

Quarcoo, K. A. (1978). The asesedwa - a unifying object of arts in Ghanaian social organization. Research Review, 66-80.

Quarcoo K. A. (1968). A debut of Ghanaian traditional visual art into liturgical arts of the Christian church of Ghana. Research Review, 4, 53-64.

Quarcoopome, N. O. (1997). Art of the Akan. Art Institute of Chicago Museum Studies, 23 (2), 135-147.

Quarcoopome, N. O. (2009). Haircuts, celebrity portraits, and stardom: Americanism and youth art in Ghana's inner cities. In S. H. Larsen (Ed.), Through African eyes: The European in African art, 1500 to present. (pp. 128-137) Detroit, MI: Detriot Institute of Arts.

Rattray, R. S. (1923). Ashanti. Oxford, UK: OUP. The Clarendon Press.

Rattray, R. S. (1927). Religion and art in Asante. London, UK: Oxford University Press. Ross, D. H. (2014a). The art of Almighty God: In his own words. African Arts, 47 (2), 8 27.

Ross, D. H. (2014b). Almighty God says stop smoking. African Arts, 47 (3), 66-75.

Ross, D. H. (2007). Come and try towards a history of Fante military shrines. African Arts, 40 (3), 12-35.

Ross, D. H. 2001. George Hughes: A portfolio. African Arts, 1 (34), 50-57.

Ross, D. H. (2000). Future remembrance: photography and image arts in Ghana by Tobias Wendl, Nancy du Plessis. African Arts, 33 (3), 87-88.

Ross, D. H. (1984). The art of Osei Bonsu. African Arts, 17 (2), 28-40.

Ross, D. H. (1982). The verbal art of Akan linguist staffs. African Arts, 16 (1), 56-67.

Ross, D. H. (1979a). Appliquéd flags of the Fante asafo. Los Angeles, CA: UCLA Museum of Cultural History Pamphlet Series, 1, 5.

Ross, D. H. (1977b). The iconography of Asante sword ornaments. African Arts, 11 (1), 16-26.

Ross, D. H. \& Garrard T.F. (Eds.). (1983). Akan transformation: Problems in Ghanaian art history. Los Angeles, CA: Museum of Cultural History Monograph Series, 21.

Silver, H. R. (1983). Foreign art and Akan aesthetics. African Arts, 16 (3), 64-67.

Silverman, R. (1986). Bono brass casting. African Arts, 19 (4), 60-64. 
Smith, F. T. (1989). Earth, vessels, and harmony among the Gurensi. African Arts, 22 (2), 60-65. Smith, F. T. (1987). Symbols of conflict and intergeneration in Frafra funerals. African Arts, 21 (1), 46-51.

Smith, F. T. (1986). Compound entryway decorations. African Arts, 19 (3), $52-59$.

Smith, F. T. (1982). Frafra dress. African Arts, 7 (3), 37-42.

Smith, F. T. (1978). Gurensi wall painting. African Arts, 11 (4), 36-41.

Warren, D. M., \& Andrews, J. K. (1977). An ethnographic approach to Akan art and aesthetics. Working Papers in the traditional arts, 3, 1-42.

Wellington, H. N-A. (2012). Fortresses, compounds and plantations: Danish cultural heritage shared with Ghana. Vandkunsten, Copenhagen, Denmark: Denmark.

Wellington, H. N-A. (2011). Stones tell stories at Osu: Memories of a host community of the Danish trans-Atlantic slave trade. Accra, Ghana: Sub Saharan Publishers.

Wendl, T. (2001). Entangled traditions: photography and history of media in southern Ghana. Journal of Anthropology and Aesthetics, 39, 78-101.

Willet, F. (1971). African art: an introduction. New York, NY: Praeger.

Woets, R. (2014). The recreation of modern and African art at Achimota School in the Gold Coast (1927-52). Journal of African History, 55, 445-465.

\section{Interviews}

Zagba Oyortey. 2013. Interview by author, May. Accra, Ghana.

B. K. Dogbe. 2015. Interview by author, September. Kumasi, Ghana. Ato Delaquis. 2015. Interview by author, September. Kumasi, Ghana. Steve Kquofi. 2015. Interview by author, September. Kumasi, Ghana. Isaac Opoku-Mensah. 2015. Interview by author, September. Winneba, Ghana. Adolph Agbeh. 2015. Interview by author, September. Winneba, Ghana. Patience Sersah. 2015. Interview by author, September. Winneba, Ghana.

Submitted: January 19, 2016 / Published: May 30, 2016 